Jurnal Ekonomi Syariah Teori dan Terapan p-ISSN: 2407-1935, e-ISSN: 2502-1508. Vol. 8 No. 5

September 2021: 559-569; DOI: 10.20473/vol8iss20215pp559-569

\title{
THE FACTORS THAT AFFECT ZIS FUNDRAISING ON ZAKAT MANAGEMENT ORGANIZATION IN 2016-2019
}

\section{FAKTOR-FAKTOR YANG MEMPENGARUHI PENGHIMPUNAN DANA ZIS PADA ORGANISASI PENGELOLA ZAKAT TAHUN 2016-2019}

\author{
Dwi Rizka Rahmawati iD, Dina Fitrisia Septiarini \\ Departemen Ekonomi Syariah - Fakultas Ekonomi dan Bisnis - Universitas Airlangga \\ dwi.rizka.rahmawati-2017@feb.unair.ac.id*,dina.fitrisia@feb.unair.ac.id
}

\begin{abstract}
ABSTRAK
Studi ini bertujuan untuk menganalisis pengaruh penerapan PSAK 109 pada laporan keuangan, penyaluran dana ZIS, rasio penggunaan dana amil, dan rasio margin kontribusi dana amil terhadap penghimpunan dana ZIS oleh OPZ pada tahun 2016-2019. Studi ini menggunakan pendekatan kuantitatif dengan teknik regresi data panel dengan pengambilan sampel menggunakan purposive sampling. Penelitian ini menemukan bahwa secara parsial, pengaruh penerapan PSAK 109 pada laporan keuangan terhadap penghimpunan dana ZIS oleh OPZ berpengaruh positif tidak signifikan. Pengaruh penyaluran dana ZIS terhadap penghimpunan dana ZIS oleh OPZ berpengaruh positif signifikan. Pengaruh rasio penggunaan dana amil dan rasio margin kontribusi dana amil terhadap penghimpunan dana ZIS ole OPZ berpengaruh negatif tidak signifikan. Sedangkan secara simultan, penerapan PSAK 109 pada laporan keuangan, penyaluran dana ZIS, rasio penggunaan dana amil, dan rasio margin kontribusi dana amil berpengaruh secara signifikan terhadap penghimpunan dana ZIS oleh OPZ tahun 2016-2019. Penelitian ini diharapkan bisa meningkatkan kinerja amil dan bisa lebih menerapkan standar akuntansi dalam pencatatan keuangannya. Bagi regulator bisa digunakan sebagai acuan dalam menetapkan besaran bagian dana amil.
\end{abstract}

Kata Kunci: PSAK 109, Penghimpunan Dana ZIS, Penyaluran Dana ZIS, Rasio Dana Amil

\begin{abstract}
The purpose of this study is to analyze the effect of the application of PSAK 109 on financial statements, the distribution of ZIS funds, the ratio of the use of amil funds, and the ratio of the contribution margin of amil funds to the ZIS fundraising by OPZ in 2016-2019. This study uses a quantitative approach with panel data regression with purposive sampling. This study found that partially the effect of the application of PSAK 109 on the financial statements on the ZIS fundraising by OPZ has positive effect but insignificant. The effect of the distribution of ZIS funds on the ZIS fundraising by OPZ has a significant positive effect. The effect of the ratio of the use of amil funds and the ratio of the contribution margin of amil funds to the ZIS fundraising by OPZ has a negative effect and insignificant. Yet, simultaneously, the application of PSAK 109 in financial statements, distribution of ZIS funds, ratio of use of amil funds, and ratio of contribution margin of amil funds significantly affects the ZIS fundraising by OPZ in 2016-2019. This research is expected to improve the performance of amil and the amil is able to better apply accounting standards in their financial records. For regulators, this can be used as a reference in determining the portion of fund for the amil.
\end{abstract}

Keywords: PSAK 109, ZIS Fundraising, Distribution of ZIS Funds, Amil Fund Ratio

\author{
Informasi artikel \\ Diterima: 21-04-2021 \\ Direview: 05-06-2021 \\ Diterbitkan: 30-09-2021 \\ ${ }^{*}$ Korespondensi (Correspondence): \\ Dwi Rizka Rahmawati \\ Open access under Creative \\ Commons Attribution-Non \\ Commercial-Share A like 4.0 \\ International Licence \\ (CC-BY-NC-SA)

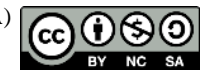

\section{INTRODUCTION}

Muslims are obliged to carry out Zakat in order to worship Allah and to eliminate social inequality through the fulfillment of the economic needs of the community. Zakat can be directly given from muzakki to mustahik consisting of 8 ashnaf, and can also be distributed through the Zakat 
Management Organization (ZMO). One of the activities of zakat management organizations is to collect zakat from muzakki. So long as Muslims still fulfill their zakat through the Zakat Management Organization (ZMO), the Zakat Management Organization (ZMO) can function and run well, and the other way round. Therefore, the Zakat Management Organization (ZMO) must deploy any effort to increase the understanding, obedience and enthusiasm of Muslims to fullfill their zakat through zakat institutions (Rahman, 2015).

Kadry (2014) in Azizah's research (2018) stated that the amount of current potential zakat is not sync with ZIS fundraising and distribution activities. To determine how far the amil zakat activities carry out their operational activities, good governance guidelines are needed, namely the efficiency and effectiveness of the performance of financial institutions.

To realize good financial reports, an organization must implement the valid accounting standards which must be based on PSAK 109, namely zakat and infaq / alms accounting. The zakat fundraising ratio in Indonesia is very small due to several factors including the lack of public knowledge, lack of insight and socialization, low trust in Zakat Management Organizations (ZMO), and the fact of the culture of that Indonesian people who prefer to distribute their zakat directly to mustahik desired. The lack of public trust in the Zakat Management Organization (ZMO) can bring about an impact of the failure to improve the ability of fulfilling the zakat now. Therefore, to increase the public trust, Zakat Management Organization (ZMO) should implement a good accounting system in controling the zakat (Rahman, 2015)

The study by Sulastiningsih and Urfiyya (2019) found that the variable of the application of PSAK 109 had a significant negative impact on the performance of ZIS fundraising Organization in DIY with the balance scorecard method. Furthermore, Latifah (2016) found that the application of PSAK 109 had a significant positive impact on the management of zakat. In addition, Bahri and Arif (2020) showed that the distribution including 8 asnaf, based on the Zakat Core Principle (ZPC) gave the effectiveness of the distribution of $87 \%$ or in the category of being effective.

This study differs from the previous studies in that the previous ones only explained the extent of effectiveness and efficiency of zakat fundraising organization in collecting and distributing the zakat funds, the effect of the application of PSAK 109 on zakat management, yet, not even a single study described the effect of the application of PSAK 109, distribution, and the ratio of amil funds on ZIS fundraising, because the ratios used by ZMO were only issued in 2020. In other words, the previous studies analyzed only the level of effectiveness and efficiency of its performance. They did not analyze the level of the effect of the application of PSAK 109 on the ratios used. Therefore, the writer of this study is interested in conducting a study to identify the factors of ZIS fundraising by ZMO. Thus, this study will analyze the effect of the application of PSAK 109, the distribution of ZIS funds, the ratio of the use of amil funds, and the contribution margin ratio of amil funds partially and simultaneously on the ZIS fundraising by ZMO in 2016-2019.

\section{THEORETICAL BASIS}

\section{PSAK 109}

One way of making financial reports is by deploying the accounting system, and zakat accounting standards are the rules that govern financial confirmation, measurement, and reports. PSAK number 109 concerning ZIS accounting aims to create good and complete reports and recording, so that the financial statements can be read and accessed by the public. The Financial Accounting Standards of PSAK No. 1 (IAI, 2004:4) in Trianto's research (2018) state that financial statements are periodic reports that are regulated based on valid accounting guidelines related to the financial position of individuals, social or business organizations.

\section{Zakat Management Organization}

Zakat Management Organization is an organization that operates in the activities of collecting and distributing zakat, infaq/alms. According to the laws and regulations in Indonesia, there are 2 Zakat Management Organizations (UU no 23, 2011).

1. Badan Amil Zakat Nasional (BAZNAS) is the institution responsible for controlling the zakat nationally. 
2. The Amil Zakat Institution (LAZ) is an institution founded by the community and assigned to help BAZNAS in collecting, distributing, and utilizing the zakat.

The Zakat Management Organization is assigned to collect and distribute ZIS funds. Setyaningsih, H., (2008) in the study by Wikaningtyas and Sulastiningsih (2015) stated that zakat fundraising is an activity to collect certain assets that are recommended by Allah to be given to mustahik. While zakat distribution is the activity of delivering the zakat funds, infaq / alms from muzakki to mustahik. Based on Law number 23 of 2011 regarding zakat management, it is explained that zakat must be distributed to the community based on the provisions of Islamic law (Law no 23, 2011 articles 25-26).

\section{Amil Fund Ratio}

The Center for Strategic Studies - National Amil Zakat Agency (2020) states that the ratio of amil funds is a ratio that assesses the effectiveness of using amil funds in carrying out activities in zakat institutions. Assessment of amil funds is also used to assess the efficiency and effectiveness of amil funds used for the collection and distribution of zakat, infaq and alms activities.

1. The ratio of the use of amil funds is used to know the amount of funds needed for amil in the operational activities of collecting and distributing the ZIS funds.

$$
\text { Utilization of Amil funds }=\frac{\text { utilization of amil funds }}{\text { amil funds received+initial balance }} \times 100 \%
$$

2. The contribution margin ratio of amil funds is used to see the amount of margin obtained by amil in its operational activities of collecting and distributing the ZIS funds

\section{Muzakki Trust Concept}

$$
\text { Amil fund contributionMargin }=\frac{\text { surplus (defisit)of amil fund }}{\text { amil fund received }}
$$

Muzakki are people who are obliged to pay zakat on their assets. It also means the obligation of a Muslim who has property and has fulfilled the requirements to pay zakat. Then, they are obliged to distribute their zakat to those who are entitled to receive it. In addition to Muslims who have assets, zakat is also intended for people who are dependent, healthy in mind, and capable.

Mustafa (2013) in Riyaldi and Yusra's (2020) study stated that in the zakat management system, muzakki trust is a vital aspect for zakat management institutions. The behavior of muzakki in paying their zakat depends on their trust in the zakat institutions. Lack of trust is one of the hindrances for muzakki to pay their zakat through zakat institutions. As a result, some of them choose to give their zakat directly to the mustahik respectfully. Therefore, understanding the behavior of the compliance in paying zakat is very important for zakat management institutions in order to optimize the zakat fundraising.

\section{Transparency Concept}

Transparency means submitting reports openly, clearly, and honestly to all involved parties regarding the activities carried out by the management reported to the involved parties. Transparency is built on free and honest information. Transparency is openness in making decisions and conveying information about the condition of the company.

Zakat Management Organization must hold certain characteristic and attitude in showing the transparency of Financial Statements, namely Tabligh. Zakat Management Organizations must adhere to Allah's rules, always convey everything correctly and transparently, uphold honesty, do work with dedication and high loyalty. The principle of transparency is the principle that guarantees access or freedom for everyone to obtain information about the management of the organization, namely information about policies, the process of making and implementing it, as well as the obtained results (Septiarini, 2011).

\section{Accountability Concept}

Ar Rahman (2003: 46) in the study by Amalia and Widiastuti (2019), stated that accountability is human responsibility to Allah SWT for what he has done. In Islam, accountability serves as a form of responsibility of a human being as a caliph on earth to Allah SWT, because whatever Allah has entrusted to humans is a mandate, and everything humans do by must be accounted for in the hereafter. As explained in the Qur'an Surah Al-Muddassir verse 38 that has a meaning "Everyone is responsible for what he has done" 


\section{Hypothesis development \\ PSAK 109 and ZIS fundraising}

Zakat Management Organizations (ZMO) should apply accounting standards because it involves the accountability of all operational activities carried out. Knowing good and correct zakat accounting which is accountable for to the public, it can be traced to whomever the zakat funds, infaq / alms are distributed, so that they can improve the operational activities of the zakat management organization (ZMO). The results of study by Nofitasari (2020) state that the transparency of financial statements positively affects the level of trust in muzakki and the accountability of financial statements has a negative impact on the level of trust in muzakki.

\section{H1: The application of PSAK number 109 has a positive effect on the of ZIS fundraising by ZMO}

\section{ZIS fund distribution and ZIS fundraising}

Distribution of zakat funds, infaq/alms is an activity organized by the Zakat Management Organization (ZMO) in order to distribute funds obtained from donors which are distributed to mustahik. This is carried out to improve the performance of the Zakat Management Organization (ZMO). In this study, the amount of fund distribution is known from the amount of zakat, infaq/alms that have been distributed to mustahik. The results of study by Pohan (2017) state that FDR has a significant impact on TPF.

\section{H2: Distribution of ZIS funds has a positive effect on the ZIS fundraising by ZMO}

\section{The Ratio of the utilization of amil funds and ZIS fundraising}

The ratio of the utilization of amil funds is one of the ratios of the amil funds ratio. This ratio determines the level of effectiveness of the utilization of amil funds in carrying out the operational activities. In this study the ratio of the utilization of amil funds is calculated by dividing the amount of utilization of amil funds by the amount of the amil funds received plus the initial balance. Study by Karolina et al., (2020) states that BOPO has a significant negative effect on TPF.

\section{H3: The ratio of the utilization of amil funds has a negative effect on the ZIS fundraising by ZMO}

\section{The contribution margin Ratio of the amil funds and ZIS fundraising}

The contribution margin ratio of amil funds is the ratio used to determine the amount of shares received by amil when carrying out operational activities to collect the ZIS funds. This ratio is also used to measure the effectiveness and efficiency of the amil funds utilized. Study by Susanti (2015) states that profit has a positive and significant impact on TPF.

H4: The contribution margin ratio of the amil funds has a positive effect on the ZIS fundraising by ZMO

The effect of applying PSAK 109 on financial statements, distribution of ZIS funds, the ratio of the utilization of amil funds, and the ratio of the contribution margin of amil funds on the ZIS fundraising by ZMO

Study by Hidayat and Sunarsi (2020) found that the FDR, CAR, NPF, and BOPO variables simultaneously had a significant impact on TPF. Study by Sulastiningsih and Urfiyya (2019) also states that corporate governance, internet control, and adoption of PSAK 109 simultaneously affect the performance of ZISMO.

H5: The application of PSAK 109 in financial statements, distribution of ZIS funds, ratio of use of amil funds, and ratio of contribution margin of amil funds simultaneously affect the ZIS fundraising by ZMO

\section{RESEARCH METHOD}

This quantitative study with a quantitative approach aims to identify the relationship between the variables. Anshori and Iswati (2009:155) state that the quantitative approach identifies the relationship between variables, hypothesis testing, and the data used must be measurable so that it can produce generalizable results. This study used secondary data in the form of financial reports from BAZNAS and LAZ for 2016-2019 from the official websites of each zakat institution. The type of data in this study is panel data, a combination of cross section and time series data.

All the National Amil Zakat Agency (BAZNAS) and the Amil Zakat Institution (LAZ) in Indonesia are included as the population of this study using purposive sampling, which is in accordance 
with the standards determined by the author, namely (1) BAZNAS and LAZ in the 2016-2019 research year; (2) BAZNAS and LAZ available financial reports from 2016-2019; (3) BAZNAS and LAZ whose financial statements are as of December 31. Zakat institutions classified as in line with the criteria of the study include 3 BAZNAS and 5 LAZ, namely (1) Central BAZNAS; (2) BAZNAS West Java; (3) BAZNAS Gresik; (4) LAZ Indonesia Zakat Initiative; (5) LAS Griya Yatim \& Dhuafa; (6) LAZ Rumah Zakat; (7) LAZ Al-Fajr Indonesian Orphanage; (8) LAZ Yatim Mandiri.

The dependent variable in this study is the ZIS fundraising, an activity of collecting the zakat, infaq / alms from donors by the Zakat Management Organization (ZMO). Fundraising aims to determine the amount of funds collected from year to year. In this study, we use the annual data of the 2016-2019 financial statements.

The operational definition of the independent variable is described in the following table. Table 1.

Operasional Definision of Independent Variabel

\begin{tabular}{|l|l|}
\hline \multicolumn{1}{|c|}{ Variabel } & \multicolumn{1}{|c|}{ Measurement } \\
\hline Fundraising of ZIS (Y) & The amount of fund collected by ZMO \\
\hline Application of PSAK 109 (X1) & $\begin{array}{l}\text { The number of financial statements divided by the number of } \\
\text { components in PSAK 109 }\end{array}$ \\
\hline Distribution of ZIS fund (X2) & The amount of fund distributed to mustahik \\
\hline Rasio of utilization of amil fund (X3) & $\begin{array}{l}\text { The utilization of amil fund divided by amil fund received plus } \\
\text { initial balance multiplied by 100\% }\end{array}$ \\
\hline Rasio of amil fund contribution margin (X4) & Surplus (defisit) amil fund divided by amil fund received \\
\hline
\end{tabular}

Source: processed by the writer

The analysis technique of this research is Panel data regression analysis, a combination of time series data and cross section data. The regression equation model is as follows:

$$
\text { PHD } D_{i t}=a_{i t}+b_{1} P P_{i t}+b_{2} P Y D_{i t}+b_{3} R P G D A_{i t}+b_{4} R M K D A_{i t}+e_{i t}
$$

Di mana:

$$
\begin{array}{ll}
P H D_{i t} & =\text { ZIS fundraising each ZMO i year } \mathrm{t} \mathrm{OPZ} \mathrm{i} \\
a_{i t} & =\text { Constant coefficient } \\
b_{i t} & =\text { Regression coefficient } \\
P P_{i t} & =\text { Application of PSAK } 109 \text { each ZMO i year } \mathrm{t} \\
P Y D_{i t} & =\text { ZIS distribution each ZMO i year } \mathrm{t} \\
R P G D A_{i t} & =\text { Rasio of utilization of amil fund each ZMO i year } \mathrm{t} \\
R M K D A_{i t} & =\text { Rasio of amil fund contribution margin each ZMO } \mathrm{i} \text { year } \mathrm{t} \\
e_{i t} & =\text { Error }
\end{array}
$$

\section{Stages of determining the estimation model}

According to Prawoto (2017: 276), the panel data estimation model is determined by the following method:

1. Fixed Effect Model (FEM): assumes that each individual has different intercept. To find out the differences in each involved object, a dummy variable is used.

2. Common Effect Model (CEM): is a model that does not pay attention to the dimensions of time or individuals, so all data are assumed to be the same at different times.

3. Random Effect Model (REM): estimates panel data in which the hindrance variables may be interrelated over time and between individuals. In this model, each company has the different intercept of the error terms.

\section{Choosing the estimation model}

Widarjono (2009) used the following approach in estimating the panel data regression model:

1. Chow test. This test is used to choose the better model between Common Effect Model (CEM) or Fixed Effect Model (FEM). In testing this model, it is based on the following conditions: if the probability value is $>0.05$ then the model used is CEM, but if the probability value is $<0.05$ then the model used is FEM. 
2. Hausman test. This test is used to select the better model between Fixed Effect Model (FEM) and Random Effect Model (REM). In testing this model, it is based on the following conditions: if the probability value is $>0.05$ then the model chosen is REM, but if the probability value is $<0.05$ then the model used is FEM.

3. Lagrange Multiplier (LM) test. This test is used to choose the better model between Random Effect Model (REM) and Common Effect Model (CEM). In testing this model, it is based on the following conditions: if the Breusch-pagan probability value is $>0.05$ then the model chosen is CEM, but if the Breusch-pagan probability value is $<0.05$ then the model used is REM.

\section{Hypothesis testing}

1. Simultaneous Test (F Test)

The $\mathrm{F}$ test is used to see whether the independent variables in the study have an impact on the dependent variable simultaneously (together). If the significant level of $\mathrm{F}$ is less than $5 \%$, the independent variable has a simultaneous effect on the dependent variable. But if the F significant level is more than $5 \%$, the independent variable has no simultaneous effect on the dependent variable.

2. Test (t Test)

The t-test is conducted to see whether the independent variable partially affects the dependent variable. The test is carried out with a significance level of 5\%. If the probability of $t$ statistic is less than $5 \%$, then the independent variable has a significant effect on the dependent variable. But if the probability of $t$ statistic is more than $5 \%$, then the independent variable has no significant effect on the dependent variable.

3. Determination Coefficient Test $\left(\mathrm{R}^{2}\right)$

The Determination Coefficient Test $\left(\mathrm{R}^{2}\right)$ aims to determine the amount of capability of the model to able to explain how much the independent variable has contributed to the dependent variable. Assuming, the higher $\left(\mathrm{R}^{2}\right)$, the greater the influence of the independent variable on the dependent variable.

\section{RESULTS AND DISCUSSION}

Descriptive Statistic

Table 2.

Statistical description of Variabel

\begin{tabular}{|l|l|l|l|l|l|}
\hline & PHD & PP & PYD & RPGDA & RMKDA \\
\hline Mean & 24.58860 & 0.693750 & 24.50300 & 3.022939 & 0.090375 \\
\hline Median & 24.59063 & 0.800000 & 24.22805 & 3.035837 & 0.069696 \\
\hline Maximum & 26.39277 & 1.000000 & 26.32434 & 3.136813 & 0.296336 \\
\hline Minimum & 22.34599 & 0.400000 & 22.11689 & 2.863076 & 0.002307 \\
\hline Std. Dev. & 1.113709 & 0.183052 & 1.130180 & 0.078126 & 0.074075 \\
\hline Observasi & 32 & 32 & 32 & 32 & 32 \\
\hline
\end{tabular}

Source: processed Data (Eviews 10)

Based on table 2, the average ZIS fundraising carried out by zakat management organizations is 24.588. This shows that the average ZIS fundraising by zakat management organizations has been effective. The minimum value for raising funds is 22.345 while the maximum value is 26.392 with a standard deviation of 1.113 . This is because some zakat management organizations are very good at collecting funds from the public.

\section{Determination Coefficient Test $\left(\mathbf{R}^{2}\right)$}

The determination coefficient test $\left(\mathrm{R}^{2}\right)$ is carried out to count the proportion of the influence of the independent variable in explaining the dependent variable. Below are the results of the determination coefficient test $\left(\mathrm{R}^{2}\right)$ by using the Fixed Effect Model (FEM): 
Table 3.

Results of Determination coefficient (R2)

\begin{tabular}{|l|l|}
\hline R-squared & 0.998847 \\
\hline Adjusted R-squared & 0.998212 \\
\hline
\end{tabular}

Source: Processed Data (eviews 10)

The determination coefficient test of the adjusted $\mathrm{R}^{2}$ score gained the value of 0.998212 or $99 \%$. Thus, it can be concluded that the dependent variable of ZIS fundraising by CMO can be explained $99 \%$ by the dependent variable in the model, and the rest of $1 \%$ is explained by other factors outside the model.

\section{F Test (Simultaneous)}

Whether all independent variables significantly affect the dependent variables in this study, they were tested using $\mathrm{F}$ test (simultaneous). The standard in accepting $\mathrm{H}_{0}$ and $\mathrm{H}_{1}$ is looking at the probability value of $\mathrm{F}$ statistic. If the probability value is less than the significance level of $0.05(5 \%)$ then $\mathrm{H}_{0}$ is rejected.

Table 4.

Results of F Test (Simultan)

\begin{tabular}{|l|l|}
\hline F-statistic & 1574.712 \\
\hline Prob(F-statistic) & 0.000000 \\
\hline
\end{tabular}

Source: Processed Data (eviews 10)

The results of the F test with Fixed Effect Model (FEM) testing give the probability F statistic value of 0.000000 which indicates a score below 0.05 . This can be concluded that $\mathrm{H}_{0}$ is rejected, and the variables for the application of PSAK 109, distribution of ZIS funds, the ratio of the utilization of amil funds, and the contribution margin ratio of amil funds has a significant simultaneous effect on the ZIS fundraising by CMO.

\section{T Test (Partial Test)}

The t-test is useful in indicating the level of significance of the independent variable affecting the dependent variable. Here are the results of the t-test:

Table 5.

Results of t Test

\begin{tabular}{|l|l|l|l|l|}
\hline Variabel & Coefficient & Std. Error & t-Statistic & Prob. \\
\hline C & 10.28304 & 1.219886 & 8.429505 & 0.0000 \\
\hline PP & 0.116472 & 0.076295 & 1.526603 & 0.1425 \\
\hline PYD & 0.688680 & 0.083116 & 8.285809 & 0.0000 \\
\hline RPGDA & -0.875476 & 0.453309 & -1.931302 & 0.0677 \\
\hline RMKDA & -0.038235 & 0.197683 & -0.193416 & 0.8486 \\
\hline
\end{tabular}

Source: Processed Data (eviews 10)

\section{PSAK 109}

In accordance with the results of the panel data regression and the previous t-test, it was found that the application of PSAK 109 had an insignificant effect on the ZIS fundraising by ZMO in 20162019. The results of this study are the same as research by Lazia and Subardjo (2017) stating that reports of zakat, infaq/alms have no impact on the level of trust of muzakki. Thus, it can be concluded that the application of PSAK 109 has no effect on the ZIS fundraising by zakat management organizations. Whether or not the zakat institutions apply accounting standards in recording their financial statements, the operational activities will not much be affected, and people still trust in distributing their zakat funds, infaq / alms to the zakat institutions / agencies respectfully.

Basically, financial statements are not the main basis for making decisions in determining where to pay zakat, infaq/alms because muzakki, in carrying out their obligations to pay zakat, infaq/alms, purely want to worship Allah regardless of the level of income they receive and the financial statements system applied. (Lazia and Subardjo, 2017). 


\section{Distribution of ZIS funds}

Based on the results of the panel data regression and the previous t-test, it was found that the ZIS fund distribution variable had a significant effect on the ZIS fundraising by ZMO in 2016-2019. This shows that the greater the ZIS funds given to mustahik, the greater the level of trust of the muzakki to provide zakat funds, infaq/alms to zakat institutions and the higher the funds collected by the zakat management organizations.

The same as Pohan's research (2017), the results of this study found that the FDR variable had a significant impact on TPF. This is due to the ability of the zakat institutions to manage the funds received from muzakki well and to give the funds to people who are entitled to receive, so that the trust of muzakki to give zakat funds, infaq/alms through zakat institutions will increase. Basically the distribution of zakat plays a very strategic role in the development of national zakat. Zakat distribution is the spearhead in efforts to improve the quality of life of mustahik and zakat distribution programs will affect public perception and trust regarding the zakat management, whether or not the zakat goes to the right target. This can be seen from the types of distribution consisting of distribution and utilization respectfully. Distribution is a consumptive zakat distribution activity, while utilization is a productive zakat distribution activity. When the mustahik gets a productive zakat distribution, he can utilize the zakat funds as business capital and later he can transform himself to be a muzakki not to be a mustahik forever. As a result, it can be perceived that zakat amil institutions/agencies have distributed zakat funds to the right mustahik and are able to increase public trust to provide zakat funds to legal entities (Beik, 2019).

\section{The ratio of the utilization of Amil fund}

Based on the results of panel data regression and previous t-test, it is known that the variable ratio of the utilization of amil funds has no significant effect on the ZIS fundraising by ZMO in 2016-2019, meaning that the lower the utilization of amil funds, the better the level of ZIS fundraising carried out by $\mathrm{ZMO}$, and the other way round.

The ratio of the utilization of amil funds has no effect on the ZIS fundraising, as the zakat institution is a non-profit oriented institution that does not seek profit in their activities. So the amount of the amil funds utilized does not affect the level of trust of muzakki to entrust their zakat funds to the zakat institutions because basically, for the muzzaki, paying zakat is obligatory. So, any amount of amil funds used to facilitate the activities in zakat institutions will not reduce the public to provide the zakat funds through the legal institutions. Moreover, the zakat institutions do not received constant income for the operational, because the income received is based on the amount of funds from the donors.

This study contrasts with the study of Karolina et al. (2020) who stated that BOPO had a negative and significant impact on TPF. So, the amount of the utilization of amil funds will not affect the amount of ZIS fund collection by the zakat management organizations, because the operational load of zakat management should be the obligation of amil and can be collected from zakat funds that are part of amil or part of fi sabilillah in a reasonable amount (MUI Fatwa No. 8 of 2011).

\section{Amil fund contribution margin ratio}

Based on the results of panel data regression and previous t-test, it is known that the contribution margin ratio variable for amil funds has a negative and insignificant effect on the ZIS fundraising by ZMO in 2016-2019. In other words, the lower the contribution margin of the amil funds, the better the level of ZIS fundraising carried out by the ZMO, and the other way round respectfully.

This study has the same results as the research by Zahwa (2019) which states that ROA does not have a significant effect on TPF, meaning that an increase or decrease in ROA does not affect the desire of the public to invest their funds. Thus, the level of the contribution margin of amil funds will not affect the amount of ZIS fundraising by ZMO, because zakat is principally obligatory for Muslims. So how much ever the contribution the amil makes to help run the activities in the zakat institution will not affect the muzakki's decision to give their zakat funds through legal institutions. This is because in the zakat institution there is no regulation regarding the amount of contribution that can be taken by amil in carrying out its operational activities.

Basically, zakat institutions are institutions that carry out operational activities without prioritizing the amount of profit earned, because amil works to seek the pleasure of Allah. The amil functions to regulate the amount of funds received from the community and distribute it back to the needy 
in a reasonable amount. Regardless of the contribution taken from the amil funds that can be used to help the amil operational activities, it will not affect the amount of funds collected, because the zakat institution is a non-profit oriented institution that does not seek profit in the its activities.

The effect of the application of PSAK 109 in the financial statements, distribution of ZIS funds, the ratio of the utilization of amil funds, and the ratio of the contribution margin of amil funds on the ZIS fundraising by ZMO

Based on the results of the F-test, the F-statistical probability value is 0.000000 , which means that it is below (0.05), meaning that $H_{0}$ is rejected and $H_{1}$ is accepted. Thus, the variables of the application of PSAK 109 in the financial statements, the distribution of ZIS funds, the ratio of the use of amil funds, and the ratio of the contribution margin of amil funds affect the amount of ZIS fundraising by ZMO in 20162019. Previous study by Hidayat and Sunarsi (2020) also found that FDR, CAR, NPF, and BOPO simultaneously had a significant effect on TPF. Moreover, Sulastiningsih and Urfiyya (2019), state that corporate governance, internet control, and the adoption of PSAK 109 simultaneously affect the performance of ZISMO. This further implies that the variables of the application of PSAK 109 in the financial statements, the distribution of ZIS funds, the ratio of the utilization of amil funds, and the ratio of the contribution margin of amil funds simultaneously become the factors that can determine the level of ZIS fundraising by ZMO.

\section{CONCLUSION}

1. The variable of the application of PSAK 109 in the financial statements partially has a positive and insignificant effect on the ZIS fundraising by ZMO.

2. The distribution of ZIS funds partially has a significant positive effect on the ZIS fundraising by ZMO.

3. The variables of the ratio of the utilization of amil funds and the ratio of the contribution margin of amil funds Partially have an insignificant negative effect on the ZIS fundraising by ZMO.

4. The variables of the application of PSAK 109 in the financial statements, the distribution of ZIS funds, the ratio of the utilization of amil funds, and the contribution margin ratio of amil funds simultaneously have a significant effect on the ZIS fundraising by ZMO.

\section{Suggestion}

1. For $\mathrm{ZMO}$, it is expected this study will serve as a reference and evaluation in carrying out its operational activities and will be able to improve its performance properly and based on the goals set. And the ZMO can better apply the standards in recording the financial statements and publish them so that the public can have access to them.

2. For the muzakki, this study can provide information regarding the obligation to pay zakat through legal institutions. Thus, the zakat funds can be managed properly and given to those who are entitled to receive it.

3. For further researchers, it is expected this study will serve as a reference for similar research and can provide good information, and later they can add more variables related to the factors that can affect the level of ZIS fundraising by ZMO such as income levels, consumption expenditures, accountability, transparency, etc.

4. For regulators, it is expected this study will serve as a reference in determining the amount of the share of amil funds so that the zakat institutions, such as Zakat Management Organization (ZMO), can carry out the operational activities properly.

\section{REFERENCES}

Amalia, N., \& Widiastuti, T. (2019). Pengaruh akuntabilitas, transparansi, dan kualitas pelayanan terhadap minat muzaki membayar zakat. Jurnal Ekonomi Syariah Teori dan Terapan, 6(9), 17561769. DOI: $10.20473 /$ vol6iss20199pp1756-1769

Anshori, M., \& Iswati, S. (2009). Buku ajar metodologi penelitian kuantitatif. Surabaya: Airlangga University Press (AUP).

Azizah, S. N. (2018). Efektivitas kinerja keuangan badan amil zakat nasional (BAZNAS) pada program pentasharufan dana zakat di BAZNAS Kota Yogyakarta. Jurnal Ekonomi Islam| Islamic 
Rahmawati, et al/Jurnal Ekonomi Syariah Teori dan Terapan Vol. 8 No. 5 September 2021: 559-569

Economics Journal, 6(1). DOI: https://doi.org/10.24090/ej.v6i1.2049

Bahri, E. S., \& Arif, Z. (2020). Analisis efektivitas penyaluran zakat pada rumah zakat. Al Maal: Journal of Islamic Economics and Banking, 2(1), 13-24.

Beik, Irfan Syauqi. (2019). Memahami sistim penyaluran zakat. Retrieved from https://baznas.go.id/pendistribusian/kolom/direktur-pp/274-memahami-sistim-penyaluran-zakat

Hidayat, A., \& Sunarsi, D. (2020). Faktor-faktor yang mempengaruhi dana pihak ketiga dan dampaknya terhadap profitabilitas (Survey pada BPR syariah di Jawa Barat tahun 2014-2017). Jurnal Proaksi, 7(1), 54-65. DOI: https://doi.org/10.32534/jpk.v7i1.1006

Ikatan Akuntan Indonesia. 2008. Akuntansi zakat dan infaq/sedekah ED PSAK 109. Jakarta: IAI.

Karolina, K. (2020). Pengaruh profitabilitas, kecukupan modal, risiko kredit terhadap dana pihak ketiga serta implikasinya terhadap nilai perusahaan. Jurnal SEKURITAS (Saham, Ekonomi, Keuangan Dan Investasi), 4(1), 68-79. DOI: http://dx.doi.org/10.32493/skt.v4i1.7107

Karolina, K., Nuryani, A., \& Hidayat, A. (2020). Pengaruh efisiensi operasional, kecukupan modal, risiko kredit terhadap dana pihak ketiga pada PT. Bank Perkreditan Rakyat di wilayah Tangerang. KREATIF: Jurnal Ilmiah Prodi Manajemen Universitas Pamulang, 8(2), 112-128. DOI: http://dx.doi.org/10.32493/jk.v8i2.y2020.p112-128

Latifah, A. (2016). Pengaruh penerapan PSAK no. 109 tentang standar akuntansi zakat terhadap pengelolaan zakat (Survey pada 4 badan amil zakat nasional di provinsi Jawa Barat). Skripsi tidak diterbitkan. Bandung: Universitas Pasundan.

Lazia, H. M., \& Subardjo, A. (2017). Refleksi laporan ZIS berdasarkan PSAK 109 dan pengaruhnya terhadap kepercayaan muzakki Al-Jihad. Jurnal Ilmu Dan Riset Akuntansi (JIRA), 6(11).

Majelis Ulama Indonesia. (2018). Fatwa Majelis Ulama Indonesia nomor 8 tahun 2011 tentang amil zakat. Jakarta: MUI.

Nofitasari, R. F. (2020). Pengaruh transparansi dan akuntabilitas laporan keuangan terhadap tingkat kepercayaan muzakki pada lembaga amil zakat infaq dan shodaqoh Nahdatul Ulama provinsi Lampung. Skripsi tidak diterbitkan. Lampung: UIN Raden Intan Lampung.

Pohan, S. (2017). Analisis laporan keuangan untuk mengukur kinerja keuangan pada perusahaan yang go public di bursa efek Indonesia. Jurnal Mantik Penusa, 1(1).

Prawoto, B. (2017). Analisis regresi dalam penelitian ekonomi \& bisnis: Dilengkapi aplikasi SPSS dan Eviews. Jakarta: Rajawali Pers.

Pusat Kajian Strategis - Badan Amil Zakat Nasional. (2020). Rasio keuangan organisasi pengelola zakat. Jakarta: Puskas Baznas.

Rahman, T. (2015). Akuntansi zakat, infak dan sedekah (PSAK 109): Upaya peningkatan transparansi dan akuntabilitas organisasi pengelola zakat (OPZ). Muqtasid: Jurnal Ekonomi Dan Perbankan Syariah, 6(1), 141-164. DOI: https://doi.org/10.18326/muqtasid.v6i1.141-164

Riyaldi, M. H., \& Yusra, M. (2020). Mengukur tingkat kepercayaan muzakki kepada Baitul Mal Aceh. Jurnal Iqtisaduna, 6(1), 78-90. DOI: https://doi.org/10.24252/iqtisaduna.v6i1.14072

Septiarini, D. F. (2011). Pengaruh transparansi dan akuntabilitas terhadap pengumpulan dana zakat, infaq dan shodaqoh pada LAZ di Surabaya. AKRUAL: Jurnal Akuntansi, 2(2), 172-199. DOI: http://dx.doi.org/10.26740/jaj.v2n2.p172-199

Sulastiningsih, S., \& Urfiyya, K. (2019). Analisis pengaruh corporate governance, internal control dan adopsi PSAK 109 terhadap kinerja OPZIS DIY melalui metode balanced scorecard. Kajian Bisnis Sekolah Tinggi Ilmu Ekonomi Widya Wiwaha, 27(1), 25-45.

Susanti, V. S. V. (2015). Pengaruh equivalent rate dan tingkat keuntungan terhadap dana pihak ketiga (DPK) perbankan syariah di Indonesia. I-Finance: A Research Journal on Islamic Finance, 1(1), $123-142$.

Trianto, A. (2018). Analisis laporan keuangan sebagai alat untuk menilai kinerja keuangan perusahaan pada PT. Bukit Asam (Persero) Tbk Tanjung Enim. Jurnal Ilmiah Ekonomi Global Masa Kini, 8(3), 1-10. DOI: http://dx.doi.org/10.36982/jiegmk.v8i3.346

Undang-Undang Republik Indonesia Nomor 23 Tahun 2011 tentang pengelolaan zakat 
Rahmawati, et al/Jurnal Ekonomi Syariah Teori dan Terapan Vol. 8 No. 5 September 2021: 559-569

Widarjono, A. (2009). Ekonometrika pengantar dan aplikasinya. Yogyakarta: Ekonisia.

Wikaningtyas, S. U., \& Sulastiningsih, S. (2015). Strategi penghimpunan dana zakat pada organisasi pengelola zakat di kabupaten Bantul. Jurnal Riset Manajemen, 2(2), 129-140.

Zahwa, S. C. (2019). Pengaruh equivalent rate bagi hasil, profitabilitas dan jumlah kantor terhadap dana pihak ketiga (DPK) BPR Syariah di Indonesia. Skripsi tidak diterbitkan. Medan: UIN Sumatera Utara. 